\title{
A new scheme for serotyping group-G streptococci
}

\author{
S. F. LAWAL and O. DOSUNMU-OGUNBI
}

\author{
Department of Microbiology \& Parasitology, College of Medicine of the University of Lagos, PMB 12003. \\ Lagos, Nigeria
}

\begin{abstract}
Summary. Ten antisera, prepared against nine selected strains of group-G streptococci and a strain of group-A streptococci of M-type 12, were used to serotype 102 isolates of group-G streptococci by means of precipitation reactions between the sera and hot-acid extracts of the streptococci. Fifty-six (54.9\%) of the streptococci could be typed; eight serotypes were identified, of which type VIII was the most common (18.6\%). The M12 and the R28 antigens, previously recorded in group-G streptococci, were not detected. The type antigens were trypsin sensitive and resembled the $M$ antigens of group-A streptococci.
\end{abstract}

\section{Introduction}

Group - $G$ streptococci are commonly isolated from the throat and from skin lesions in some tropical countries (Ogunbi, 1971; Valkenburg et al., 1972; Ogunbi et al., $1974 a$ and $b$; Belcher $e t a l ., 1975)$. Members of this group are known to cause disease in man, including endocarditis (MacDonald, 1939), epidemic pharyngitis (Hill et al., 1969) and neonatal septicaemia (Baker, 1974). Serological typing of group-G streptococci by slide-agglutination tests for their $\mathrm{T}$ antigens has been reported (Laughton and Davies, 1957; Hill et al., 1969; Efstratiou, 1983).

We have described the detection in group-G streptococci of several type antigens resembling the $M$ antigens of the group-A streptococci (Lawal et al., 1982); now we present an extension of our precipitation-typing system and give more information about the $\mathrm{M}$-like antigens of group-G streptococci.

\section{Materials and methods}

\section{Streptococci}

The following members of group $G$ isolated in our laboratory were used for the production of antisera: the six type strains previously described (nos. 28, 25, 19, 16, 21 and 18 , representing respectively types I, II, III, IV, V and VI; see Lawal et al., 1982) and two further strains (34/ $25 / 16 / 06$ and $117 / 2968$ ) corresponding to new types, respectively VII and VIII. In addition, Dr C. A. M. Fraser of the Streptococcus Reference Laboratory, Colindale, London, had provided us with a group-G strain (R51/ 755) which possesses the R28 antigen (Maxted, 1949), and a group- $\mathrm{A}, \mathrm{M}$-type 12 strain, because this $\mathrm{M}$ antigen has been encountered in group G (Maxted and Potter, 1967); sera were also made against these. A collection of 102 group-G isolates from throat swabs and skin lesions in Nigeria was examined for type antigens.

Received 18 Feb. 1985; revised version accepted 10 Jul. 1985.

\section{Serological methods}

These have been described previously (Lawal et al., 1982), and included: preparation of typing sera in rabbits; extraction of streptococci with hot $\mathrm{HCl}$; precipitation tests for type antigens in agarose gel on microscope slides; complement-fixation tests for $\mathbf{M}$-associated protein (MAP; see Widdowson et al., 1971); and direct and indirect bactericidal tests in fresh human blood.

\section{Trypsinisation of cultures}

This was performed as described by Lancefield (1962).

\section{Virulence and protection tests}

These were made in 3-week-old laboratory mice as described by Maxted and Potter (1967). Inocula of $0.5 \mathrm{ml}$ of an overnight culture in Todd-Hewitt Broth (Difco), undiluted, and diluted 1 in 10 and 1 in 100 , were injected intravenously into the tail veins (six mice per dilution), and the animals were observed for deaths for 7 days. In the protection tests, $0.25 \mathrm{ml}$ of undiluted rabbit antiserum of homologous type was given to each of six mice $24 \mathrm{~h}$ before challenge with $0.5 \mathrm{ml}$ of a 1 in 10 dilution of culture. Controls with antiserum of heterologous type were included.

\section{Results}

The vaccine strains for the new types VII and VIII were chosen because they gave high titres in the complementfixation test for MAP (respectively 160 and 320 ) and they did not react in the precipitation test with antisera for the six previously described serotypes. Post-immunisation sera were absorbed with strains of heterologous type to remove group antibody (Lawal et al., 1982) and then gave precipitation reactions only with the homologous vaccine strain. They did not react with the group-A, M12 or the group-G, $\mathbf{R} 28$ serum.

Hot-acid extracts of 102 group-G isolates were tested in the precipitation test with the enlarged set of typing sera 
Table I. Distribution of serotypes among 102 strains of group-G streptococci

\begin{tabular}{cc}
$\begin{array}{c}\text { Serotype } \\
\text { number }\end{array}$ & $\begin{array}{c}\text { Number (and percentage) } \\
\text { of the indicated } \\
\text { serotype }\end{array}$ \\
\hline I & $5(4 \cdot 9)$ \\
II & $2(2 \cdot 0)$ \\
III & $10(9 \cdot 8)$ \\
IV & $6(5 \cdot 9)$ \\
V & $2(2 \cdot 0)$ \\
VI & $7(6 \cdot 9)$ \\
VII & $5(4 \cdot 9)$ \\
VIII & $19(18 \cdot 6)$ \\
Untypable & $46(45 \cdot 1)$ \\
\hline
\end{tabular}

(table I); 56 of them $(54.9 \%$ ) fell into one of the eight serotypes. One of the new types (VIII) proved to be the most common, forming $18.6 \%$ of the total. None of the strains gave reactions with the M12 or the R28 serum.

The acid extracts were also tested for complement fixation against a standard dose of human anti-MAP serum (Widdowson et al., 1971). The MAP antigen was detected in all but $11(10.9 \%)$ of the cultures, but titres were low ( 40 or less) in 35 of them ( $34 \cdot 2 \%$ ). All the cultures in which a type-specific antigen had been detected had an MAP titre of 80 or more; the association of these characters was significant $\left(\chi^{2} 35 \cdot 76 ; p<0.01\right)$.

Trypsinisation of the hot-acid extracts of each of the vaccine strains abolished the precipitation reaction with its homologous-type antiserum; this indicated that the type antigens were proteins.

The eight vaccine strains were tested in direct bactericidal tests in fresh blood from two donors (A and B). All showed a $>100$-fold increase in numbers in the blood of at least one of the donors, but strain $\mathrm{V}$ showed a

Table II. Relation of titre of M-associated protein (MAP) to typability

\begin{tabular}{r|cc} 
Titre of & \multicolumn{2}{c}{ Number (and percentage) of strains } \\
MAP & with the stated titre & $\begin{array}{c}\text { and with an M-like } \\
\text { antigen }\end{array}$ \\
\hline 0 & $11(10.9)$ & 0 \\
10 & $8(7.8)$ & 0 \\
20 & $8(7.8)$ & 0 \\
40 & $19(18.6)$ & 0 \\
80 & $22(21.6)$ & $22(21 \cdot 6)$ \\
160 & $28(27.5)$ & $6(5.9)$ \\
320 & $6(5.9)$ & $66(54.9)$ \\
Any & $102(100 \cdot 0)$ & 56 \\
\hline
\end{tabular}

somewhat smaller increase in the blood of donor $A$ and strains I and VII did not multiply in the blood of donor B. In indirect bactericidal tests (Maxted, 1956) in the blood of donor $\mathbf{A}$, the multiplication of all of the vaccine strains was inhibited partially (multiplication not in excess of $\times 5$ ) or completely (no multiplication) by the corresponding rabbit antiserum but not by heterologous sera.

Six of the eight vaccine strains showed some virulence for mice by the intravenous route, a 1 in 10 dilution of culture killing the following numbers (of six) mice: I, 4; III, 2; IV, 4; VI, 4; VII, 5; VIII, 4. Two of the strains (nos. II and V) were non-virulent; all six of the mice that received undiluted culture survived. In mouse-protection tests with a challenge dose of 1 in 10 culture, the rabbit antisera for types I, III and VII gave complete protection against death, and the serum for type VIII gave partial protection; but the serum for type IV was not protective.

\section{Discussion}

The addition of two typing antisera to our set resulted in a considerable increase in the percentage of typable strains, from 28.8 to 54.9 ; this was mainly, but not entirely, attributable to type VIII, which formed $18.6 \%$ of the total. All the strains in which type antigens were detected gave high titres in the complement-fixation test for MAP; this confirmed the close association of this protein with the M-like antigens in the group-G streptococci, as with the $M$ antigens in group-A streptococci.

The type antigens of group-G streptococci are destroyed by trypsin, and thus are proteins, like the group-A $M$ antigens (Lancefield, 1962). The vaccine strains for types I-VI were shown by Lawal et al. (1982) to multiply in the blood of a single donor. This property was reexamined, for all eight vaccine strains, in the blood of two different donors. Though all the strains grew in the blood of at least one of the donors, some strains grew poorly or not at all in the blood of one or other of them. This may have been due to the presence of type-specific antibody in the blood samples.

Six of the eight type strains showed some virulence for mice by the intravenous route, but two were non-virulent. Rabbit antisera against five of the six mouse-virulent strains were tested for protective action in mice. Three of the five sera gave complete and one gave partial protection, but one was inactive in this respect.

We have identified type-specific antigens in more than one-half of a collection of Nigerian group-G streptococcal strains; these resemble the $\mathbf{M}$ antigens of group-A streptococci in being trypsin-sensitive proteins that confer antiphagocytic powers on the organism in human blood, and in being associated with MAP antigens. Like M-positive group-A streptococci, a number of the group$\mathrm{G}$ streptococci-but not all of them-are mouse-virulent.

We wish to thank Professor T. Odugbemi and Dr V. O. Rotimi for their useful suggestions and invaluable criticisms, and Dr C. A. M. Fraser for the gift of cultures. 


\section{REFERENCES}

Baker C J 1974 Unusual occurrence of neonatal septicaemia due to group-G Streptococcus. Pediatrics. 53:568-570.

Belcher D W, Afoakwa S N, Osei-Tutu E, Wurapa F K, Osei L 1975 Non-group-A Streptococci in Ghanaian patients with pyoderma Lancet 2:1032.

Efstratiou A 1983 The serotyping of hospital strains of streptococci belonging to Lancefield group $\mathrm{C}$ and group G. Journal of Hygiene 90:71-80.

Hill H R, Caldwell G G, Wilson E, Hager D, Zimmerman R A 1969 Epidemic of pharyngitis due to Streptococci of Lancefield group-G. Lancet 2:371-374.

Lancefield R C 1962 Current knowledge of type-specific M antigens of group A streptococci. Journal of Immunology 89:307-313.

Laughton N, Davies J 1957 Animal strains of group G streptococci and their serological typing Journal of General Microbiology; 17:750-757.

Lawal S F, Coker A O, Solanke E O, Ogunbi O 1982 Serotypes among Lancefield group-G streptococci isolated in Nigeria. Journal of Medical Microbiology 15:123-125.

MacDonald I 1939 Fatal and severe human infections with haemolytic streptococci group G (Lancefield). Medical Journal of Australia 2:471-474.

Maxted W R 1949 Occurrence of the M Substance of Type 28 group A in streptococci of Lancefield groups B,C and G. Journal of General Microbiology 3:1-6.
Maxted W R 1956 The indirect bactericidal test as a means of identifying antibody to the $\mathbf{M}$ antigen of Streptococcus pyogenes. British Journal of Experimental Pathology 37:415 422.

Maxted W R, Potter E V 1967 The presence of type 12 M-protein antigen in group $\mathrm{G}$ streptococci. Journal of General Microbiology 49:119-125.

Ogunbi O 1971 A study of beta-haemolytic streptococci in throats, noses and skin lesions in a Nigerian (Lagos) Urban population. Nigerian Medical Journal 1:159-164.

Ogunbi O, Lasi Q, Lawal S F 1974 a An epidemiological study of beta-haemolytic streptococcal infections in a Nigerian (Lagos) Urban population. In: Haverkorn M J (ed) Streptococcal disease and the community, Excerpta Medica (International Congress series no. 317), Amsterdam, p. 282.

Ogunbi O O, Lawal S F, Lasi Q, Ogunbi O $1974 b$ Streptococcal pyoderma in a Lagos School population. Nigerian Medical Journal 4:178-180.

Valkenburg H A, Muller A S, Wolters C H L, Steenhuis E M 1972 Streptococci in Liberia and Nigeria, West Africa: In: Haverkorn M J (ed) Streptococcal disease and the community. Excerpta Medica American (International congress series no. 317) Amsterdam, p. 209.

Widdowson J P, Maxted W R, Pinney A M 1971 An Massociated protein antigen (MAP) of group A streptococci. Journal of Hygiene 69:553-564. 